\title{
Puncture Wounds by Driftwood Catfish During Bucket Baths: Local Habits of Riverside People and Fish Natural History in the Amazon
}

\author{
Ivan Sazima, PhD, BSc; Jansen Zuanon, PhD, BSc; Vidal Haddad Jr, MD, PhD \\ From the Natural History Museum, Universidade Estadual de Campinas, São Paulo, Brazil (Dr Sazima); National Institute of Amazon \\ Research, Manaus, Amazonas, Brazil (Dr Zuanon); and Botucatu Medicine School, Universidade Estadual Paulista, São Paulo, Brazil \\ (Dr Haddad Jr).
}

\begin{abstract}
Objective.-To assess the prevalence of stings by small spiny driftwood catfish (caratá) of the genus Centromochlus (Auchenipteridae) accidentally caught in buckets during bucket bathing by riverside people along the Brazilian Amazon and to determine the probability of catching specimens of these fish during random throws of a bucket into the river.

Methods.-We interviewed 27 adult residents living at the confluence of the Negro and Solimões rivers in Brazil regarding whether or not they had ever been stung by driftwood catfish while bucket bathing. To assess the likelihood of catching catfish in bathing buckets, we randomly threw a typical plastic bucket used for bathing in 4 series of 10 throws into the river at dusk or night around a floating house.

Results.-Seventeen of the 27 subjects (63\%) reported being injured by driftwood catfish during bucket bathing. Three individuals (17.6\%) had been injured 2 to 3 times, totaling 23 puncture accidents. All stings occurred at dusk or early night. In the 4 series of 10 bucket throws, we caught 3 driftwood catfish (in 1 series we did not catch any fish). Thus, the chance of catching a driftwood catfish in a single bucket throw at dusk was slightly less than $10 \%$.

Conclusions.- The prevalence of stings by driftwood catfish to people bucket bathing in this section of the Brazilian Amazon is high, partly because of the relatively high chances of catching these small catfish during random throws of a bathing bucket into the river.
\end{abstract}

Key words: bathing, puncture wounds, dangerous fish, Centromochlus, schooling habits, catfish

\section{Introduction}

In Brazil, as in much of the world, puncture wounds caused by catfish usually result from handling the netted or hooked fish. ${ }^{1,2}$ The puncture wounds are sometimes aggravated by the presence of venom glands in the skin sheath that covers the sharp and often serrated spines on the dorsal and pectoral fins of various catfish species. ${ }^{3-10}$

The riverside people who inhabit the floodplains of Amazonian white water (turbid) rivers habitually bucket bathe (Figure 1), which they do several times a day and most frequently at dusk. During bucket bathing, the peo-

Corresponding author: Vidal Haddad Jr, MD, PhD, Botucatu Medicine School (Universidade Estadual Paulista), Caixa Postal 557, 18618-000-Botucatu, Sa o Paulo, Brazil (e-mail: haddadjr@fmb. unesp.br). ple are dressed (men in shorts, women in frocks). For bathing, a person throws a bucket tied to a rope into the river, pulls it out, and empties it over him- or herself. At dusk and night the bucket often collects small spiny driftwood catfish, Centromochlus existimatus and Centromochlus heckelii (Auchenipteridae) (Figure 2), which the bather inadvertently throws onto his or her body along with the water. These spiny catfish have 3 welldeveloped and sharp spines with serrated edges, 1 in the dorsal fin and 1 in each pectoral fin, which they spread out and lock readily when frightened (Figure 3 ). This defensive behavior may result in a catfish becoming attached by its spines to several places on a bather's body.

This is a study of the prevalence of puncture wounds caused by catfish spines related to bucket bathing in a convenience sample of riverside dwellers in the Brazilian Amazon. It focuses on the bucket bathing habit, the 


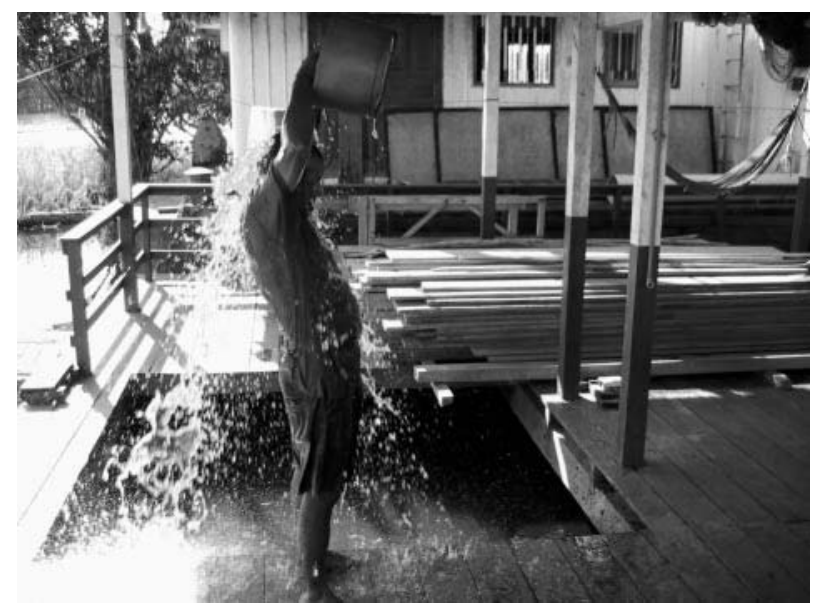

Figure 1. A riverside-dwelling person during bucket bathing at daytime in a floating house on the Solimões River, Central Amazon, Brazil. Note the position of the bucket and the water pouring (the bather holds his eyes shut during the process), as well as the typical clothing. Photograph by I.S.

circumstances of the injuries, and the natural history of the catfish in order to describe these peculiar encounters between humans and catfish.

\section{Methods}

We carried out this study along a stretch of the Solimões River near the main city Manaus, Central Amazon, Brazil. Approximately 270 people comprise the resident population in that area at the confluence of the Negro and Solimões rivers $\left(3^{\circ} 08^{\prime}-3^{\circ} 14^{\prime} \mathrm{S} ; 59^{\circ} 53^{\prime}-59^{\circ} 58^{\prime} \mathrm{W}\right)$. To assess the incidence of injuries caused by catfish during bucket bathing, we haphazardly selected adult riverside people as a convenience sample and interviewed them about their personal experience with wounds caused by 2 species of small (up to $10 \mathrm{~cm}$ in total length) driftwood catfish, $C$ existimatus and $C$ heckelii, locally called caratai. The interview was simple with 5 main questions: 1) Have you been injured by the caratárwhile bucket bathing? 2) Did the accident occur during the day or at dusk or night? 3) On which body parts did the caratá1get stuck? 4) How did you manage to remove the attached caratá 5 ) How did you treat the wound? Because bucket bathing is a widespread habit in the Brazilian Amazon, our random sample would indicate how frequent catfish injuries could be among the riverside people. We allowed ourselves to be stung a few times by both species of Centromochlus while handling live specimens in order to personally experience the injury. Additionally, to determine the likelihood that a bather would accidentally catch a driftwood catfish in a bathing

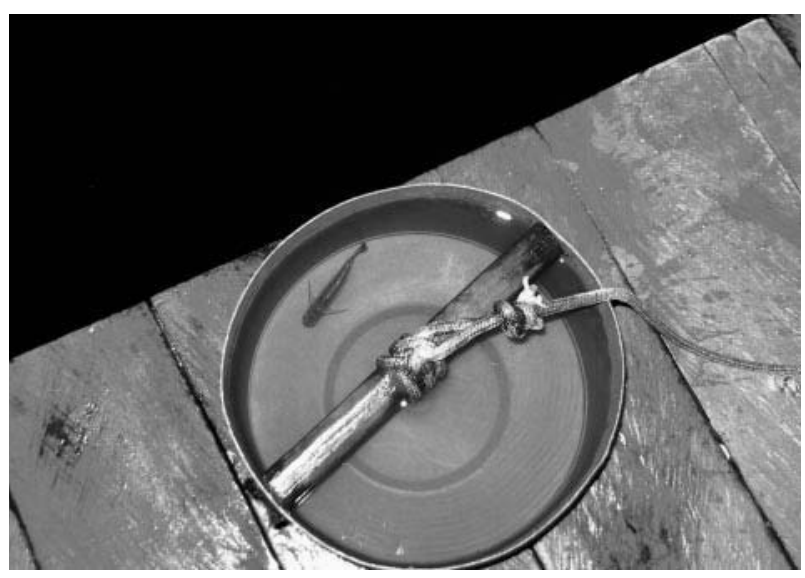

Figure 2. A driftwood catfish, Centromochlus heckelii, in a plastic bucket. The fish was caught while the person threw the bucket randomly into the water at dusk around a floating house in the Solimões River, Central Amazon, Brazil. Photograph by I.S.

bucket, we randomly threw a typical plastic bucket used for bathing in 4 series of 10 throws into the river at dusk or night around a floating house. We recorded the general habits of $C$ heckelii around floating houses and boats anchored at the riverbank.

\section{Results}

The sample consisted of 27 interviewed subjects (18 men, 9 women; 25-60 years old), who represent approximately $10 \%$ of the local population. Seventeen subjects $(63 \%)$ reported being injured by driftwood catfish during bucket bathing. In 3 of these cases (17.6\%), the subjects were injured 2 to 3 times, totaling 23 puncture accidents. All reported cases occurred at dusk (17001900 hours; $52.9 \%$ ) or at early night (1900-2100 hours; $47.1 \%)$. Additionally, 2 wounds not related to bucket bathing occurred when subjects jumped into the water to wash soap off their bodies.

The most commonly injured body places were the upper limbs (mainly hands), followed by head and neck and lower limbs. The trunk (including the back and upper portion of the buttocks) was the least injured place (Table). The injured individuals removed the catfish immediately and with bare hands, sometimes with the help of another person when the fish was stuck in a hard-toreach body part (eg, on the back). In 1 instance, a bather who was frightened by a catfish that was attached to the upper portion of his buttock struck his own buttock with his hand and got stuck with a second catfish spine. Another person then removed the fish.

In 3 of the reported cases, the catfish spine broke off 


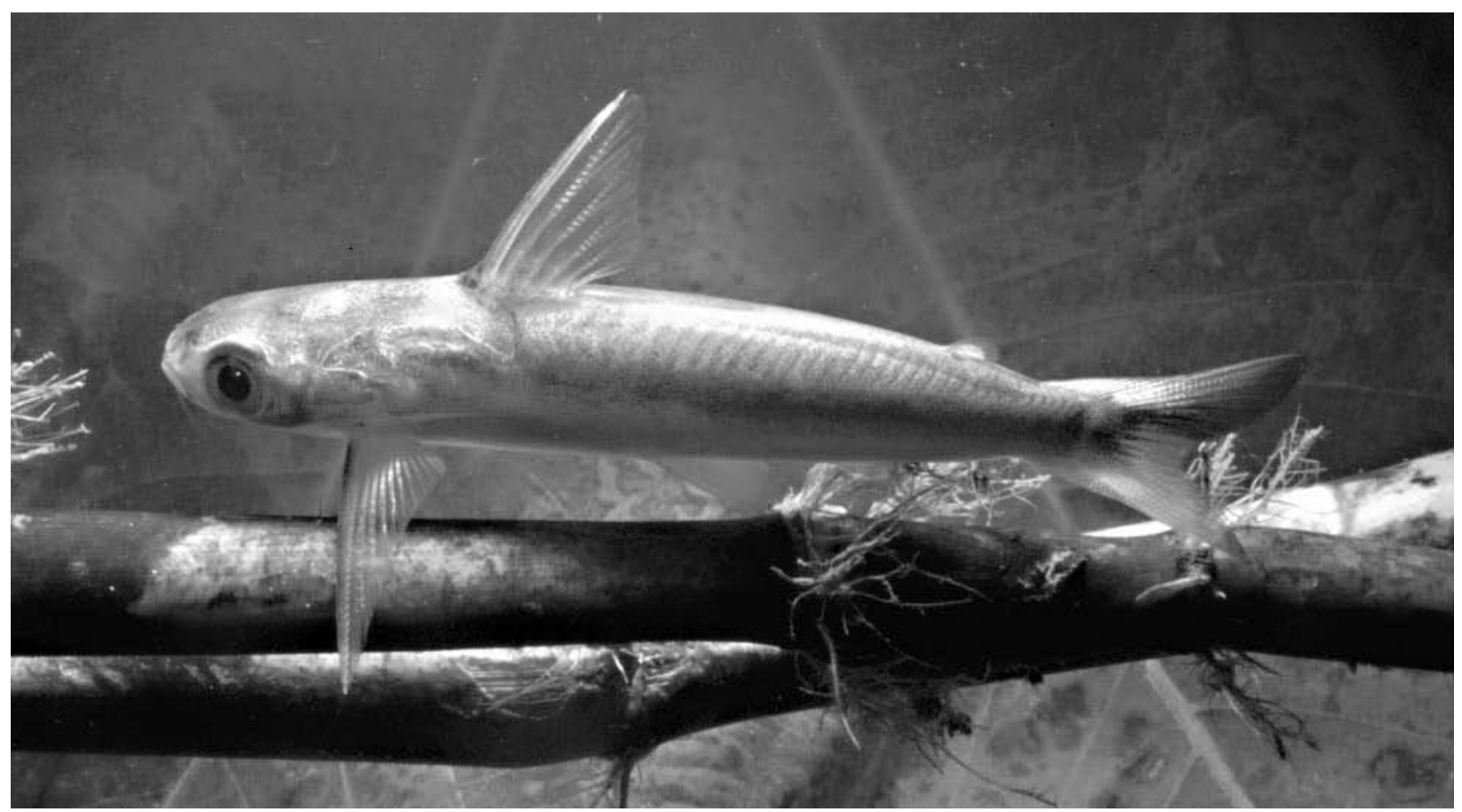

Figure 3. Lateral view of a driftwood catfish, Centromochlus heckelii, caught angling in the Solimões River, Central Amazon, Brazil (actual size $7.8 \mathrm{~cm}$ in total length). Note the long and sharp serrate spines of the dorsal and pectoral fins. Voucher specimen in the fish collection of the Natural History Museum, Universidade Estadual de Campinas (access no. ZUEC 6246). Photograph by I.S.

within the wound (head, forearm, and leg) and the wound became infected and swollen. In 1 of these instances (forearm), the broken spine had to be surgically removed at a local hospital. Victims reported the intensity of the pain as varying from a local, quickly receding pain to a long-lasting (up to 1 hour) severe pain. One victim complained that the pain from a driftwood catfish sting was similar to that from a freshwater stingray (Potamotrygonidae) sting.

Two of us (I.S., J.Z.) experienced wounds by both

Distribution, number, and frequency (\%) of puncture wounds caused by spines of the driftwood catfish (Centromochlus existimatus and Centromochlus heckelii) on human body parts during bucket baths in the Solimões River, Central Amazon, Brazil

\begin{tabular}{lr}
\hline \multicolumn{1}{c}{ Body part } & $N(\%)$ \\
\hline Head and neck & $4(17.4)$ \\
Trunk & $3(13.0)$ \\
Upper limb & $12(52.2)$ \\
Lower limb & $4(17.4)$ \\
Total & $23(100)$ \\
\hline
\end{tabular}

species of Centromochlus while handling catfish in the bucket or while fishing. The serrate spine edges rendered the extraction of the attached fish difficult and painful; our skin and subcutaneous tissue was pulled during the process. The pain subsided in about half an hour. The puncture wound was accompanied by local reddening and a slight swelling without further complications.

In the 4 series of 10 bucket throws, we caught 3 driftwood catfish (in 1 series we did not catch any fish). Thus, the chance of catching one in a bucket thrown during bucket baths at dusk in this section of the river is slightly less than $10 \%$.

\section{Discussion}

Wounds caused by catfish spines during bucket bathing may be regarded as a highly unusual injury type in the medical literature. Most, if not all, of the reported human injuries attributed to catfish occur while manipulating angled or netted specimens or after stepping on dead catfish or broken spines discarded by fishermen. ${ }^{1,2}$

The widespread habit of bucket bathing by riverside people along the Amazon Basin stems from the turbid waters of the large rivers combined with a fear of being 
attacked by potentially dangerous fish (eg, piranhas, blood-feeding candirus) or caimans. The coincidence of human bathing at dusk with the nocturnal Centromochlus catfish sets the stage for this peculiar injury type. Additionally, because humans have impaired visual acuity during twilight and under the dim light of the boats and floating houses, the small, light-colored catfish are frequently undetected in the bathing bucket.

Both $C$ existimatus and $C$ heckelii are widespread in the Amazon Basin and are particularly abundant in white-water rivers. ${ }^{11}$ They hide during most of the daytime and come to the water surface at dusk and night to feed on terrestrial invertebrates that fall into the water. ${ }^{11}$ These catfish live in schools and frequently congregate around floating houses and boats, especially along the riverbank, because they are attracted by the regular (and thus predictable) discharge of food leftovers as well as by the light-attracted insects that fall into the water. Under these circumstances, dozens of catfish may swim erratically close to the water surface in zigzag movements, scanning the upper water layer in search of food (J.Z. and I.S., personal observation). Thus, the natural history features of the driftwood catfish combined with the bucket bathing habit of riverside people lead to a peculiar form of local, Amazonian injury.

The disproportionate pain at the site of the spine puncture, when compared with the small wound, strongly suggests the presence of toxins in the mucus or the skin sheath covering the spines, as recorded for species in the catfish families Pimelodidae and Heptapreridae. ${ }^{1,2}$ Although there may be differences in the wound severity caused by the catfish spines, the reported variation in the pain intensity might be related mainly to an individual person's sensitivity. The presence, amount, and chemical characteristics of toxin in Centromochlus spines are features open to investigation.

A relatively high frequency of riverside people are injured by Centromochlus catfish during bucket bathing. These stings appear to manifest local symptoms only, and the absence of further complications even without medication is indicative of the relatively low to mild severity of driftwood catfish wounds. The mild local infection (probably of bacterial origin) in 3 cases in which the spine broke within the wound may have been caused by inadequate wound care. Similarly, such inadequate care might have contributed to the only injury that required a surgical procedure. Careful search for and removal of spine fragments from wounds are recommended as a basic procedure in such cases. ${ }^{9}$

Bucket bathing is widespread among Brazilian Amazon riverside people in spite of the relatively high incidence of injuries by catfish stings. Aside from the fact that the pain quickly subsides and that the incidence of further complications is very low (ie, negligible hazards), bucket bathing is a daily component of the riverside people's habits, with its roots in the culture of original Amerindian people. However, it seems to be more of a cultural feature than a necessity in most situations observed during the present study, for almost all the houses we visited had a simple bathroom with a shower.

\section{Conclusions}

The prevalence of stings by driftwood catfish to people who bucket bathe in this section of the Brazilian Amazon is high, partly because of the relatively high chances of catching these small catfish during random throws of a bathing bucket into the river. Utilization of showers for bathing or careful inspection of bathing buckets before using water drawn from the river might reduce the prevalence of this injury.

\section{Acknowledgments}

We thank the riverside people who gladly agreed to our interviews; F. P. Mendonça, C. Sotero da Silva, J. Paulino da Silva, and Suzy Araújo for helping in the field; and the "Projeto Catalão" of the Instituto Nacional de Pesquisas da Amazonia for financial support and logistics. I.S. receives financial support from the Conselho Nacional de Desenvolvimento Cientifico e Tecnologico and Fundacao de Amparo a Pesquisa do Estado de São Paulo.

\section{References}

1. Haddad V Jr. Atlas de Animais Aquáticos Perigosos do Brasil: Guia Médico de Identificação e Tratamento [Atlas of Dangerous Aquatic Animals of Brazil: A Medical Guide for Identification and Treatment]. São Paulo, Brazil: Editora Roca; 2000.

2. Haddad V Jr, Gonzales MT. Acidentes provocados por mandis (Pimelodus sp): estudo clnico em uma comunidade de pescadores em Santa Maria da Serra (SP) [A clinical study of the injuries caused by freshwater catfishesmandis (Pimelodus $s p$ ) - in fishermen of Santa Maria da Serra-Sa ^o Paulo State-Brazil)VI Simposium of Brazilian Society of Toxinology. March 15-18, 2000; São Pedro, São Paulo State, Brazil: Brazilian Society of Toxinology; 2000.

3. Halstead BW. Poisonous and Venomous Marine Animals of the World. 2nd ed. Princeton, NJ: Darwin Press; 1988.

4. Baack BR, Kucan JO, Zook EG, Russell RC. Hand infections secondary to the catfish spines: case reports and literature review. J Trauma. 1991;31:1432-1436.

5. Mann JW, Werntz JR. Catfishes stings to the hand. J Hand Surg. 1991;16A:318-321. 
6. McKinstry DM. Catfishes stings in United States: case report and review. J Wildl Med. 1993;4:293-303.

7. Shepherd S, Thomas SH, Stone CK. Catfish envenomation. J Wildl Med. 1994;5:67-70.

8. Das SK, Johnson MB, Cohly HHP. Catfish stings in Mississippi. South Med J. 1995;88:809-812.

9. Blomkalns AL, Otten EJ. Catfish spine envenomation: a case report and literature review. Wilderness Environ Med. 1999; 10:242-246.
10. Ajmal N, Nanney LB, Wolfort SF. Catfish spine envenomation: a case of delayed presentation. Wilderness Environ Med. 2003;14:101-105.

11. Ferraris CJ Jr. Family Auchenipteridae (Driftwood catfishes). In: Reis RE, Kullander SO, Ferraris CJ Jr, eds. Checklist of the Freshwater Fishes of South and Central America. Porto Alegre, Rio Grande do Sul, Brazil: EDIPUCRS; 2003:470-482. 